\title{
Response of Wheat Varieties (Triticum aestivum L. and Triticum durum Desf.) to Sowing Time
}

\author{
M.D. Patel*, M.S. Dabhi, A.K. Patel, H.A. Desai and Chatra Ram \\ Wheat research Station, S.D.A.U., Vijapur, Mahesana-384570, Gujarat, India \\ *Corresponding author
}

\begin{tabular}{|l|}
\hline K e y w o r d s \\
Wheat, Genotype, \\
$\begin{array}{l}\text { Maturity, GDW 1255, } \\
\text { Sowing, Durum and } \\
\text { soil fertility }\end{array}$ \\
\hline Article Info \\
\hline $\begin{array}{l}\text { Accepted: } \\
\text { 12 September } 2018 \\
\text { Available Online: } \\
\text { 10 October } 2018\end{array}$ \\
\hline
\end{tabular}

\section{A B S T R A C T}

Among various production factors for wheat crop, time of sowing and wheat varieties are crucial ones influencing productivity. Onset of various phenophases of wheat crop is greatly related with the prevailing temperature at that time. Any deviation from optimum temperature for onset of phenophase may drastically reduce the crop productivity. Similarly wheat varieties play vital role under different temperature situation. Hence, considering these two aspects a field experiment was conducted on sandy loam soil at Centre of Excellence for Research on Wheat, Sardarkrushinagar Dantiwada Agricultural University, Vijapur to study the "Response of wheat varieties (Triticum aestivum L. and Triticum durum Desf.) to sowing time" in North Gujarat conditions" during rabi season of the year 2012-13. The experiment comprising of twelve treatment combinations was laid out in Split Plot Design with four replications. The treatment consisted of three sowing times i.e., $15^{\text {th }}$ November (Timely), $1^{\text {st }}$ December (Late) and $15^{\text {th }}$ December (Very late) and four wheat varieties (viz., GW 11, GW 173, GW 322 and GDW 1255 (d)). The results of experiment revealed that the plant population at initial and harvest, harvest index were remained unaffected due to different sowing times. Significantly higher Plant height $(80.2 \mathrm{~cm})$, number of spikes $/ \mathrm{m}^{2}$ (328.1), length of spike $(8.7 \mathrm{~cm})$ number of grains per spike $(57.5), 50 \%$ heading (65.2), Test weight (52.7), protein content $(14.81 \%)$ grain $\left(4716 \mathrm{~kg} \mathrm{ha}^{-1}\right)$ and straw $\left(7068 \mathrm{~kg} \mathrm{ha}^{-1}\right)$ yield was found when crop sown on $15^{\text {th }}$ November. The result of mean data of varieties indicated that the different growth parameters viz., plant height, days to 50 per cent heading, days to physiological maturity were significantly influenced and maximum values of these parameters were recorded by wheat variety GW 322. However, plant population at initial and harvest, number of spikes per meter $^{-2}$ and harvest index were remained unaffected due to different varieties. Significantly higher values of yield attributes viz., plant height $(85.1 \mathrm{~cm})$, length of spike $(9.2 \mathrm{~cm})$ number of grains per spike (52.8) and 50\% heading (62.7) were observed in variety GW 322 while, test weight $(54.2 \mathrm{gm})$ and protein content (14.9\%) was recorded significantly higher by variety GW 1255 . The wheat variety GW 322 produced significantly higher grain yield $4408 \mathrm{~kg} \mathrm{ha}^{-1}$ and straw yield $6612 \mathrm{~kg} \mathrm{ha}^{-1}$. The increase was $0.4,10.2$ and 11.9 per cent in grain yield and $0.4,10.3$ and 11.9 per cent in straw yield as compared to GW 11, GW 173 and GDW 1255, respectively. 


\section{Introduction}

Wheat [Triticum aestivum (L.) emend. Fiori \& Paol.] is the most important staple food crop of the world and emerged as the backbone of India's food security. It is grown all over the world for its wider adaptability and high nutritive value. It is an important winter cereal contributing about $38 \%$ of the total food grain production in India. Wheat straw is an important source of fodder for a large animal population in India. In India, wheat is the second most important cereal crop after rice covering an area of 30.79 million hectares. Total annual production of wheat in India is 98.51 million tonnes with the productivity of 3.20 tonnes per hectare during 2017-18 (Anon. 2017-18). India is the second largest wheat producer (approximately 12 per cent world's wheat production) and consumer after China. In Gujarat, wheat is an important rabi crop and is grown almost throughout the state with 1.05 million hectares area under cultivation, total production of 3.05 million tonnes and an average yield of 2.89 tonnes per hectare during 2017-18 (Anon. 2017-18).

There are many factors, which are responsible for low average yield of wheat in this tract. Therefore, some efforts have been made to increase the yield by introduction of high yielding varieties, balanced fertilizer application \& efficient use of irrigation facilities. But, still there are certain factors on which attention have not been given to increase the per hectare yield of wheat. One of such environmental factor is date of sowing. This factor affects the yield of wheat crop considerably.

Recently developed new varieties of wheat have potential to replace the old established varieties of the command area. Sowing time significantly influenced the growth, yield attributes, grain and straw yields. There are still many factors, which are responsible for low average yield of wheat in this tract. One of such environmental factors is untimely planting and it affects yield of wheat crop considerably (Saini et al., 1988). Another important aspect is lack of improved varieties, which are having short maturity and suitable under late sown condition due to relatively shorter growing period available to crop. Moreover, varieties also vary both in yield and nutrient uptake under late sown condition (Singh et al., 1997). Wheat varieties preferably photo and thermo insensitive nature generally suit to a wider range of sowing times in irrigated condition as they could maintain a good level of seed yield even in late sown condition. New varieties of wheat have been developed in the recent pasts which have higher yield potential even under delayed sowing with higher degree of tolerance to high temperature as well as diseases and insect pest resistance to check varieties. Sowing time significantly influences the growth, yield attributes, grain and straw yield.

Keeping in view the aforesaid facts, the present study is being undertaken to evaluate the performance and adaptability of newly developed varieties of wheat to a wider range of sowing dates in irrigated conditions under agro-ecosystem of Northern part of Gujarat.

\section{Materials and Methods}

A field experiment was conducted on sandy loam soil at Centre of Excellence for Research on Wheat, Sardarkrushinagar Dantiwada Agricultural University, Vijapur to study the "Response of wheat varieties (Triticum aestivum L. and Triticum durum Desf.) to sowing time" in North Gujarat conditions" during rabi season of the year 2012-13. The experiment comprising of twelve treatment combinations was laid out in Split Plot Design with four replications. The treatment consisted of three sowing times i.e., $15^{\text {th }}$ November (Timely), $1^{\text {st }}$ December (Late) and $15^{\text {th }}$ 
December (Very late) and four wheat varieties (viz., GW 11, GW 173, GW 322 and GDW 1255 (d)). The soil of experimental plot was loamy sand in texture. The soil was low in organic carbon $(0.39 \%)$ available nitrogen $\left(183 \mathrm{~kg} \mathrm{ha}^{-1}\right)$ and medium in available phosphorous (49.32 $\mathrm{kg} \mathrm{ha}^{-1}$ ) and potash $\left(298.78 \mathrm{~kg} \mathrm{ha}^{-1}\right)$. The wheat varieties were sown with seed rate of $100 \mathrm{~kg} \mathrm{ha}^{-1}$, with spacing of $20.0 \mathrm{~cm}$ in between two rows. The economics was workout on current market price basis. Nitrogen was given as per recommended dose in the form of urea in which half dose of nitrogen applied as basal dose at the time of sowing and other half dose in two equal split. The full dose of phosphorus from SSP and potash from sulphate of potash was given as basal at the time of sowing. The values off "F" was worked out and compared with the values of table $F$ at 5 per cent level of significance. The value of S.Em. \pm C.D. and C.V. per cent were also calculated (Cochran and cox, 1967).

\section{Results and Discussion}

\section{Effect of date of sowing}

The data presented in Table 1 and 2 showed that, among the date of sowing, date of sowing $15^{\text {th }}$ November (Timely) recorded significantly the highest grain yield $\left(4716 \mathrm{~kg} \mathrm{ha}^{-1}\right)$. The same trend was found in straw yield, were it was recorded significantly the highest in $S_{1}$ $\left(15^{\text {th }}\right.$ November (Timely)). Increase in grain yield $\mathrm{kg} \mathrm{ha}^{-1}$ was 8.8 and 26.6 per cent as well as straw kg ha ${ }^{-1} 8.7$ and 26.5 per cent higher as compared to late and very late $\left(1^{\text {st }}\right.$ December and $15^{\text {th }}$ December) sowing times, respectively. The higher grain and straw yield was observed on date of sowing $15^{\text {th }}$ November (Timely), which might be due to the fact that timely ( $15^{\text {th }}$ November) sowing of wheat mitigated the heat stress and simultaneously, the wheat crop had enjoyed better and congenial weather parameters with better development of growth and yield attributes which in turn resulted in higher yield. The findings are in conformity with those reported by Kumar et al., (2004), Zende et al., (2005), Shirpurkar et al., (2008), Man, M.K. (2010), Jhanji, S. and Gill (2011), Jat Lokesh kumar et al., (2013) and Md. Parwaize Alam et al.,(2013).

The result showed that the date of sowing $S_{1}$ $\left(15^{\text {th }} \quad\right.$ November (Timely)) recorded significantly the higher plant height $(80.2 \mathrm{~cm})$, Earhead $/ \mathrm{m}^{2}$ (328.1), length of spike $(8.7 \mathrm{~cm})$, days required to $50 \%$ heading (65.2 days), grains/earhead (57.5) and test weight (52.7 gm). This was due to the fact that timely sowing condition of wheat provided better adoptability of weather parameters like, lower gape between minimum and maximum temperature, relative humidity, lower evapotranspiration leading to better availability of soil moisture and nutrients, which in turn favoured to profuse growth in terms of more taller plant and late or very late sowing conditions restricted the growth in terms of shorter plants. The results are in agreement with those reported by Tyagi et al., (2003), Zende et al., (2005), Man (2010), Jhanji and Gill (2011) and Jat Lokesh Kumar et al., (2013).

While protein content $(14.81 \%)$ was found significantly higher in the date of sowing $15^{\text {th }}$ December (Very late). This was might be due to very late $\left(15^{\text {th }}\right.$ December $)$ sowing or increase in temperature which favoured synthesis of amino acids but simultaneously, due to rise in temperature the grain development was retarded or grains of the wheat were shriveled resulting higher protein content in lower dry matter of the grains.

\section{Effect of varieties}

The data presented in Table 2 showed that, effect of varieties on grain and straw yield 
found significant. The grain yield $(4716 \mathrm{~kg}$ $\mathrm{ha}^{-1}$ ) found significantly higher in variety $\mathrm{V}_{3}$ (GW 322), however it was at par with variety $\mathrm{V}_{1}$ (GW 11). The same trend was found in straw yield, were it was recorded significantly the higher in variety $V_{3}(\mathrm{GW} 322)$, while it was at par with variety $\mathrm{V}_{1}(\mathrm{GW} 11)$. The increase in yield was $0.4,10.2$ and 11.9 per cent in grain yield and $0.4,10.3$ and 11.9 per cent in straw yield as compared to GW 11, GW 173 and GDW 1255.

The higher grain and straw yield was observed with variety $\mathrm{V}_{3}$ (GW 322) which might be due to fact that in general, the aestivum wheat varieties (GW 322 and GW 11) have higher capacity of uptake of nitrogen, phosphorus, potash and other macro and micro nutrients and also have more consumption and utilization power leading to higher dry matter accumulation and their translocation in different growth and yield attributes resulting higher grain and straw yield compared to durum wheat GDW 1255. The findings are in close agreement with those reported by Mishra et al., (2000), Jadhav and Karanjikar (2001), Rajput (2001), Tyagi et al., (2003), Patel (2005), Verma et al., (2005) Shripurkar et al., (2008) and Man, M.K. (2010). The result showed that the variety $\mathrm{V}_{3}$ (GW 322) recorded significantly the higher plant height $(85.1 \mathrm{~cm})$, length of spike $(9.2 \mathrm{~cm})$, days required to 50 $\%$ heading (62.7 days), grains/earhead (52.8) and protein content $(14.81 \%)$, While test weight $(52.7 \mathrm{gm})$ was found significantly higher in variety GDW 1255 (d), This was because of fact that the variety GW 322 have unique genetic makeup with more utilization of power of fertilizers and other nutrients with late maturity characteristics leading to higher dry matter accumulation and translocation in plant parts in terms of length of spike and number of grains per spike resulting obtained the higher values than other varieties.

Table.1 Growth and yield parameters of wheat genotypes at different date of sowing under irrigated conditions

\begin{tabular}{|c|c|c|c|c|c|c|}
\hline Treatments & $\begin{array}{l}\text { Plant } \\
\text { Height } \\
(\mathrm{cm})\end{array}$ & $\begin{array}{c}\text { Ear } \\
\text { head } / \mathrm{m}^{2}\end{array}$ & $\begin{array}{l}\text { Length } \\
\text { of spike } \\
\text { (cm) }\end{array}$ & $\begin{array}{l}\text { Days to } \\
50 \text { per cent } \\
\text { heading }\end{array}$ & $\begin{array}{l}\text { Grains/ } \\
\text { Ear head }\end{array}$ & $\begin{array}{c}\text { Test } \\
\text { weight } \\
\text { (g) }\end{array}$ \\
\hline \multicolumn{7}{|l|}{ Date of sowing: } \\
\hline$S_{1}: 15^{\text {th }}$ November (Timely) & 80.2 & 328.1 & 8.7 & 65.2 & 57.5 & 52.7 \\
\hline$S_{2}: 1^{\text {st }}$ December (Late) & 74.8 & 298.5 & $8 . .6$ & 60.0 & 50.2 & 45.0 \\
\hline $\mathrm{S}_{3}: \mathbf{1 5}^{\text {th }}$ December (Very Late) & 73.8 & 233.3 & 7.6 & 55.0 & 43.1 & 40.6 \\
\hline S. Em. \pm & 1.47 & 9.85 & 0.12 & 0.66 & 1.38 & 0.73 \\
\hline LSD $(P=0.05)$ & 5.09 & 34.07 & 0.43 & 2.28 & 4.76 & 2.53 \\
\hline CV (\%) & 7.72 & 13.74 & 6.01 & 4.39 & 10.95 & 6.34 \\
\hline \multicolumn{7}{|l|}{ Varieties : } \\
\hline$V_{1}:$ GW 11 & 81.6 & 290.4 & 8.6 & 58.0 & 51.9 & 49.6 \\
\hline$V_{2}:$ GW 173 & 67.7 & 298.0 & 7.5 & 58.7 & 50.4 & 42.7 \\
\hline$V_{3:}$ GW 322 & 85.1 & 284.9 & 9.2 & 62.7 & 52.8 & 38.0 \\
\hline $\mathrm{V}_{4}:$ GDW 1255 (d) & 70.8 & 273.2 & 7.9 & 61.0 & 45.9 & 54.2 \\
\hline S. Em. \pm & 1.17 & 10.13 & 0.13 & 0.95 & 1.21 & 1.02 \\
\hline LSD (P=0.05) & 3.40 & NS & 0.38 & 2.76 & 3.50 & 2.96 \\
\hline CV (\%) & 5.33 & 12.25 & 5.52 & 5.47 & 8.32 & 7.66 \\
\hline $\mathbf{S X ~ V}$ & NS & NS & S & NS & $\mathrm{S}$ & $\mathrm{S}$ \\
\hline
\end{tabular}


Table.2 Yield, quality and $\mathrm{BC}$ ratio of wheat genotypes at different date of sowing under irrigated conditions

\begin{tabular}{|c|c|c|c|c|c|}
\hline Treatments & $\begin{array}{c}\text { Protein } \\
\text { content } \\
(\%)\end{array}$ & $\begin{array}{c}\text { Grain } \\
\text { Yield } \\
\left(\mathrm{Kg} \mathrm{ha}^{-1}\right)\end{array}$ & $\begin{array}{c}\text { Straw } \\
\text { yield (Kg } \\
\left.\mathrm{ha}^{-1}\right)\end{array}$ & $\begin{array}{c}\text { Harvest } \\
\text { index } \\
(\%)\end{array}$ & BCR \\
\hline \multicolumn{6}{|l|}{ Date of sowing: } \\
\hline$S_{1}: 1^{\text {th }}$ November (Timely) & 13.19 & 4716 & 7068 & 40.00 & 2.59 \\
\hline $\mathbf{S}_{2}: \mathbf{1}^{\text {st }}$ December (Late) & 13.50 & 4302 & 6453 & 40.12 & 2.38 \\
\hline$S_{3}: 1^{\text {th }}$ December (Very Late) & 14.81 & 3462 & 5193 & 39.99 & 1.98 \\
\hline S.Em. \pm & 0.19 & 105.09 & 163.91 & 0.076 & - \\
\hline LSD ( $P=0.05)$ & 0.65 & 363.70 & 567.22 & NS & - \\
\hline CV $(\%)$ & 5.42 & 10.11 & 10.51 & 0.75 & - \\
\hline \multicolumn{6}{|l|}{ Varieties : } \\
\hline$V_{1}:$ GW 11 & 13.6 & 4391 & 6583 & 39.99 & 2.34 \\
\hline $\mathrm{V}_{2}:$ GW 173 & 13.9 & 3958 & 5933 & 40.18 & 2.11 \\
\hline $\mathrm{V}_{3:}$ GW 322 & 12.9 & 4408 & 6612 & 40.00 & 2.35 \\
\hline $\mathrm{V}_{4}: G D W 1255(d)$ & 14.9 & 3882 & 5824 & 39.99 & 2.34 \\
\hline S. Em。 \pm & 0.19 & 85.16 & 125.30 & 0.092 & - \\
\hline LSD $(P=0.05)$ & 0.56 & 247.12 & 363.61 & NS & - \\
\hline CV (\%) & 4.87 & 7.09 & 6.96 & 0.79 & - \\
\hline S X V & NS & $\mathrm{S}$ & $\mathrm{S}$ & NS & - \\
\hline
\end{tabular}

The findings are in agreement with Bahera (1994), Kumar et al., (1994), Tyagi et al., (2003), Patel (2005) and Verma et al., (2005). However, was not found significant.

\section{Interaction effect of sowing times and varieties $(\mathbf{S} \times \mathbf{V})$}

Interaction effect between sowing times and wheat varieties $(\mathrm{S} \times \mathrm{V})$ found significant in respect of length of spike $(\mathrm{cm})$, number of grains per spike, 1000-grain weight, grain and straw yield $\left(\mathrm{kg} \mathrm{ha}^{-1}\right.$ as shown in Table $1 \mathrm{a} \&$ $1 b$.

This was because of better and congenial weather parameters enjoyed by wheat varieties up to $1^{\text {st }}$ December sowing i.e. optimum and suitable cold spell which favoured and enhanced the values of growth and yield attributes which reflected on grain and straw yield. The findings are in closed agreement with findings of Jadhav and Karanjikar (2001), Tyagi et al., (2003) Shirpurkar et al., (2008), Tahir Muhammad et al., (2009) and Man, M.K. (2010).

\section{Economics of different treatments}

Economics play important role in deciding the adoption of particular treatment by the farmers. Therefore, the gross realization, net realization and benefit cost ratio (B.C.R.) were calculated for date of sowing and varieties.

Among date of sowing time maximum gross ( $92216 \mathrm{ha}^{-1}$ ) and net realization ( $56656 \mathrm{ha}^{-1}$ ) with maximum $\mathrm{BCR}$ value of 2.59 were obtained under $S_{1}\left(15^{\text {th }}\right.$ November (Timely)) sowing date.

Among varieties maximum gross $83752 \mathrm{ha}^{-1}$ ) and net realization ( $\left.48192 \mathrm{ha}^{-1}\right)$ with 
maximum BCR value of 2.35 were obtained under variety $\mathrm{V}_{3}(\mathrm{GW} 322)$.

On the basis of the results, it can be concluded that for securing higher yield and net return, wheat variety GW 322 should be sown for timely sowing $\left(15^{\text {th }}\right.$ November) and GW 11 should be sown for late sowing ( $1^{\text {st }}$ December) on sandy loam soil of North Gujarat conditions.

\section{References}

Anonymous, (2017-18). http://www.agricoop. nic.in.

Behra, A.K. (1994). Response of wheat varieties to sowing dates. Indian Journal of Agronomy. 39 (1): 171-173.

Cochran WG, Cox GM. Experimental Designs, John Willey and Sons. Inc. New York. 1967, 546-568.

Jadhav, A.G. and Karanjikar, P.N. (2001). Response of new wheat genotypes to different dates of sowing under irrigated conditions. Annals of Agricultural Research. 22 (2): 295-296

Jat, Lokesh Kumar, Singh, S. K., Latera, A.M., Singh, R.S. and Patel C. B. (2013). Effect of dates of sowing and fertilizer on growth and yield of Wheat (Triticum aestivum L.) in an Inceptisol of Varanasi (UP). Indian Journal of Agronomy. 58 (4): 611-614.

Jhanji, S. and Gill, D. S. (2011). Phenological Development and Heat Unit Requirerment of Wheat under Different dates of Sowing. Indian J. Agric. Res. 45 (2): 161-166.

Kumar, R., Shashimadan and Mohd. Yunus. (1994). Effect of planting date on yield and quality in durum varieties of wheat. Haryana Agricultural University Research Journal. 24: 186-188.

Man, M.K. (2010) Response of bread wheat (Triticum aestivum L. and Triticum durum Desf.) genotypes to different sowing time in North Gujarat Agroclimatic conditions. M.Sc. (Agri.), Thesis.

Md. Parwaize, A., Satyender, K., Nayar Ali, Ramprasad, M., Nargis, K., Rajni, K. L. and Tajwar, I. (2013). Performance of wheat varieties under different sowing dates in Jharkhand, Birsa Agricultural University, Ranchi. Journal of Wheat Res. 5(2): 61-64.

Mishra, D.K., Khan, R.A. and Baghel, M.S. (2000). Stability of wheat varieties under various dates of sowing. Annals of Agricultural Research. 21 (4): 564566.

Patel, D.K. (2005). Response of irrigated wheat (Triticum aestivum L. and Triticum durum Desf.) to Biofertilizer under varying fertility levels. M.Sc. (Agri.), Thesis Submitted to Sardarkrushinagar Dantiwada Agricultural University, Sardarkrushinagar.

Rajput, R.L. (2001). Study on production efficiency of wheat varieties in Northern Madhya Pradesh. Bhartiya Krishi Anusandhan Patrika. 16 (1/2): 9597.

Saini, A.D., Dadhwal, V.K. and Nanda, R. (1988). Pattern of changes in yield of "Kalyansona" and Sonalika varieties of wheat in sowing date experiments at different locations. Field crop abstract; 42: 67-77.

Shirpurkar, G.N., Wagh, M. P. and Patil, D.T. (2008). Comparative performance of wheat genotypes under different sowing dates. Agricultural Science Digest. 28 (3): 231-232.

Singh, S.B. and Sharma, Bhanu Prakash (1997). Response of wheat (Triticum aestivum) cultivars to irrigation. Indian Journal of Agronomy, 42(2): 387-388.

Tyagi, P.K., Pannu, R.K., Sharma, K.D., Choudhary, B.D. and Singh, D.P. (2003). Effect of sowing time on 
performance of wheat varieties. Annals of Biology. 19 (2): 119-122.

Verma, R.N., Nirala, R.K. and Ashwani, Kumar (2005). Response of wheat varieties to phosphorus application under late sown condition in Central
Uttar Pradesh. Farm Science Journal. 14 (1): 52-53.

Zende, N.B., Sethi, H.N., Karunakar, A.P. and Jiotode, D.J. (2005). Effect of sowing time and fertility levels on growth and yield of durum wheat genotypes. Research on Crops. 6 (2): 190-191.

\section{How to cite this article:}

Patel, M.D., M.S. Dabhi, A.K. Patel, H.A. Desai and Chatra Ram. 2018. Response of Wheat Varieties (Triticum aestivum L. and Triticum durum Desf.) to Sowing Time. Int.J.Curr.Microbiol.App.Sci. 7(10): 1555-1561. doi: https://doi.org/10.20546/ijcmas.2018.710.174 